\title{
8. MESOZOIC CALCAREOUS NANNOFOSSILS, DEEP SEA DRILLING PROJECT SITES 415 AND 416, MOROCCAN BASIN
}

\author{
Pavel Čepek, Bundesanstalt für Geowissenschaften und Rohstoffe, Hannover, Federal Republic of Germany \\ and \\ S. Gartner and Thomas Cool, Department of Oceanography, Texas A\&M University, College Station, Texas
}

\section{INTRODUCTION}

Cretaceous sediments were recovered at Sites 415 and 416, drilled during DSDP Leg 50. Jurassic sediments were only found in Hole 416A. Figure 1 shows the site locations and Figure 2 shows the calcareous-nannofossil zonation of the cored interval.

Calcareous nannofossils from 24 samples of Hole 415A and 194 samples of Hole 416A were studied on smear slides and identified with a light microscope. Species discussed are listed in Table 1. Abundance and preservation of the calcareous nannofossil species were determined for all samples. Estimates of abundance were made with the light microscope at a magnification of $\times 1560$. Species are recorded as: abundant (A), more than 25 specimens per traverse; common (C), 6-25 specimens per traverse; few $(F), 3-5$ specimens per traverse; and rare (R), 1-2 specimens per traverse.

Distribution of nannofossils of Holes 416A and 415A is shown in Figures 3 (back pocket, this volume) and 4, respectively.

\section{CALCAREOUS-NANNOFOSSIL BIOSTRATIGRAPHY AND ZONATION}

\section{Jurassic}

Many papers have been published about Jurassic calcareous nannofossils and several zonations-Stradner (1963), Prins (1969), Worsley (1971), and Rood et al. (1973) - have been proposed. We used the zonation of Barnard and Hay (1974) for this paper.

Jurassic (Tithonian) sediments were penetrated only in Hole 416A of the Leg 50 drilling. Occurrence and abundance of the Jurassic nannofossil species are shown on Figure 3 (back pocket).

\section{Parhabdolithus embergeri Zone}

Authors: Barnard and Hay (1974).

Definition: Interval from the first occurrence of Parhabdolithus embergeri (Noel) to the first occurrence of Nannoconus colomii (de Lapparent).

Important common species: Parhabdolithus embergeri (Noel), Conusphaera mexicana Trejo, and Polycostella beckmanii Thierstein. ian).

Stage: Tithonian (upper Kimmeridgian to Portland-

Remarks: The boundary between this zone and the Nannoconus colomii Zone is in this paper recognized by the first occurrence of Parhabdolithus asper (Stradner) and by the first common occurrence of Polycostella senaria Thierstein. The latter species was also a rare constituent in two samples below the Jurassic/Cretaceous boundary. Nannoconus colomii (de Lapparent) is rare at Hole 416A and first occurs in the middle part of the Berriasian. Stephanolithion laffittei Noel, Rucinolithus wisei Thierstein, and Lithraphidites carniolensis Deflandre, which, according to Thierstein (1976), first occur at the base of the Berriasian, were recorded at Hole 416A in the upper part of the Berriasian interval or within the lower Valanginian to upper Hauterivian. This zone is present only in the interval between Samples 416A-57, CC to 416A-53-2, 45-46 cm.

\section{Cretaceous}

We used the Cretaceous zonation of van Hinte (1976) for this study, as given in Figure 2. It incorporates the zonations of Bukry (1974), Roth (1973), Thierstein (1973), and others.

\section{Nannoconus colomii Zone}

Authors: Worsley (1971), modified by Thierstein (1971).

Definition: Interval from the first occurrence of Nannoconus colomii (de Lapparent) to the first occurrence of Cretarhabdus angustiforatus (Black).

Stage: Berriasian.

Remarks: It was difficult to recognize both zonal boundaries in accordance with the definition of this zone. A small number of Nannoconus colomii (de Lapparent) first occur 6 meters above the lower limit of this zone and the species is missing in much of the Berriasian interval. The first occurrence of Cretarhabdus angustiforatus (Black) does not coincide with the upper boundary of this zone, but is about 10 meters above the Berriasian/Valanginian boundary.

In this paper we used the first occurrence of Parhabdolithus asper (Stradner) and the first common occurrence of Polycostella senaria Thierstein to define the lower boundary of this zone. The top of this zone is marked by the first occurrence of Bipodorhabdus colligatus (Black), Calcicalathina oblongata (Worsley), Diadorhombus rectus (Worsley), and Tubodiscus verenae Thierstein. The zone was recognized only in Hole 416A (Samples 53-2, $26 \mathrm{~cm}$ to $48-1,86-87 \mathrm{~cm}$ ).

\section{Cretarhabdus angustiforatus Zone to Lithraphidites bollii Zone}

This zone is defined as the interval from the first nccurrence of Bipodorhabdus colligatus (Black), Calci- 


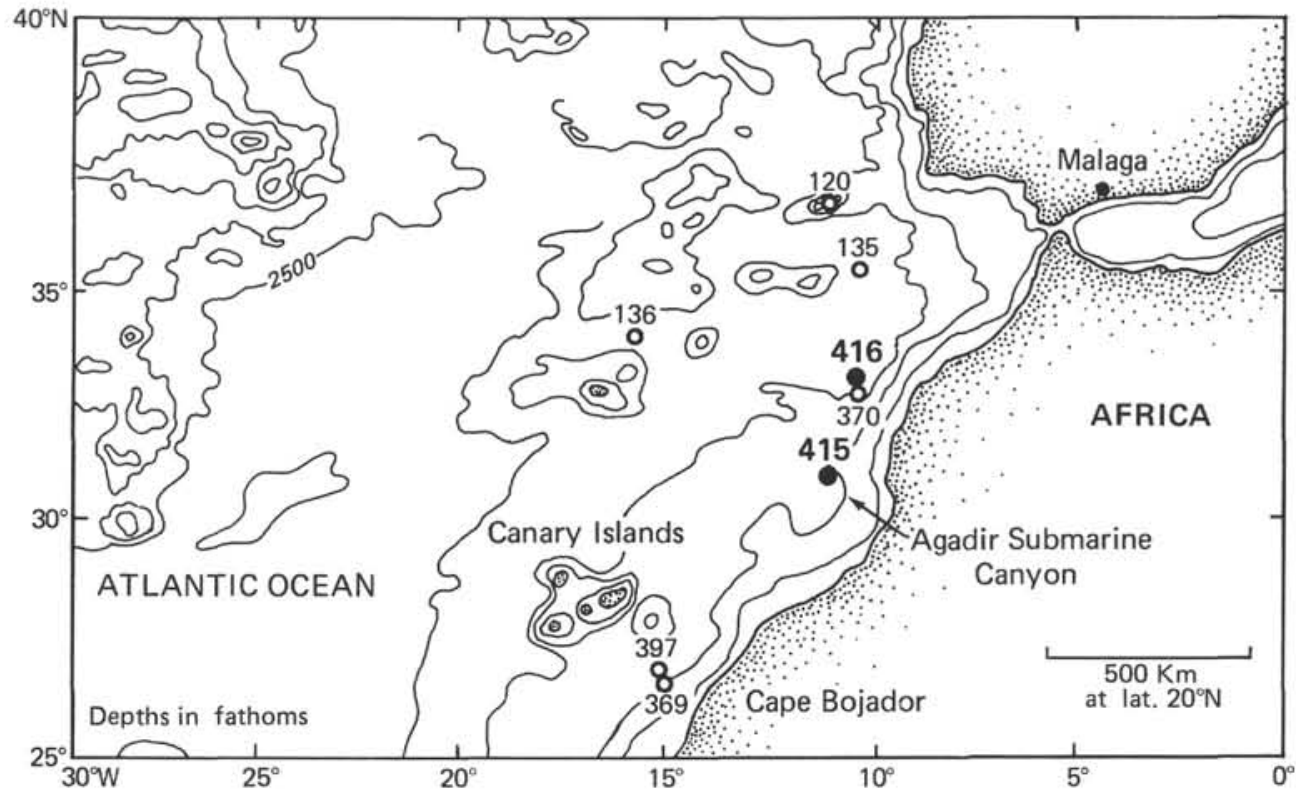

Figure 1. Location of DSDP Sites 415 and 416.

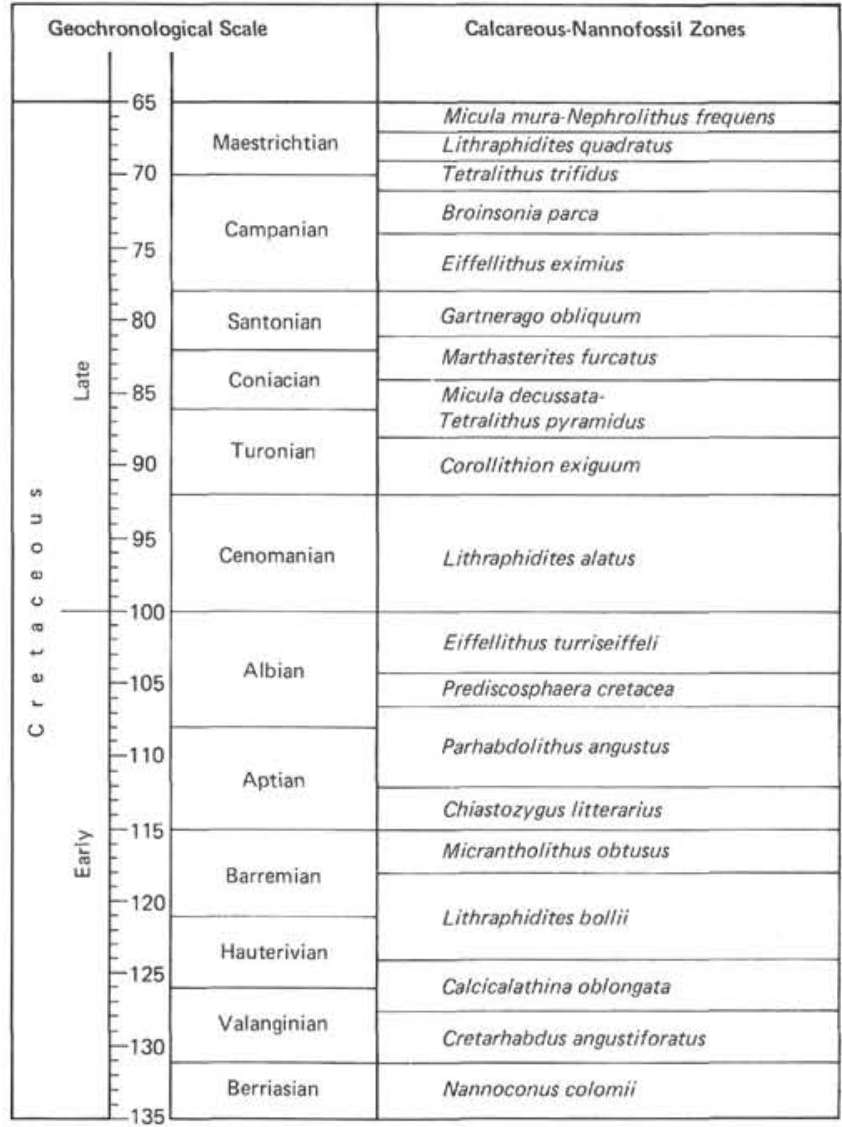

Figure 2. Cretaceous nannofossil zonation used in this report correlated with the geochronological scale of van Hinte (1976).
TABLE 1

Nannofossil Species Considered in This Report, Listed Alphabetically by Specific Name

Corollithion achylosum (Stover)

Lithraphidites alatus Thierstein

Podorhabdus albianus Black

Cretarhabdus angustiforatus (Black)

Parhabdolithus angustus (Stradner)

Parhabdolithus asper (Stradner)

Watznaueria barnesae (Black)

Polycostella beckmannii Thierstein

Broinsonia bevieri Bukry

Flabellites biforaminis Thierstein

Watznaueria biporta Bukry

Watznaueria britanica (Stradner)

Lithraphidites carniolensis Deflandre

Cruciellipsis chiastia (Worsley)

Markalius circumradiatus (Stover)

Bipodorhabdus colligatus (Black)

Nannoconus colomii (de Lapparent)

Watznaueria communis Reinhardt

Cretarhabdus conicus Bramlette and Martini

Biscutum constans (Gorka)

Cretarhabdus coronadventis Reinhardt

Prediscosphaera cretacea (Arkhangelsky)

Chiastozygus cuneatus Lyul'eva

Cruciellipsis cuvillieri (Manivit)

Watznaueria deflandrei

Podorhabdus dietzmanni (Reinhardt)

Zygodiscus diplogrammus (Deflandre and Fert)

Cribrospherella ehrenbergi (Arkhangelsky)

Zygodiscus elegans Gartner

Parhabdolithus embergeri (Noel)

Broinsonia enormis (Shumenko)

Zygodiscus erectus (Deflandre)

Reinhardtites fenestratus (Worsley)

Lithastrinus floralis Stradner

Scapholithus fossilis Deflandre and Fert

Tranolithus gabalus Stover

Sollasites horticus (Stradner, Adamiker and Maresch) 
TABLE 1 - Continued

Mitosia infinitae Worsley

Stephanolithion laffittei Noel

Diazomatholithus lehmani Noel

Chiastozygus litterarius (Gorka)

Cretarhabdus loriei Gartner

Tetralithus malticus Worsley

Cyclagelosphaera margereli Noel

Watznaueria martelae (Noel)

Vagalapilla matalosa (Stover)

Conusphaera mexicana Trejo

Calcicalathina oblongata (Worsley)

Micrantholithus obtusus Stradner

Tranolithus orionatus (Reinhardt)

Manivitella pemmatoidea (Deflandre and Manivit)

Diadorhombus rectus Worsley

Polycostella senaria Thierstein

Corollithion signum Stradner

Parhabdolithus splendens Deflandre

Vagalapilla stradneri (Rood, Hay and Barnard)

Cretarhabdus surrirellus (Deflandre)

Eiffellithus turriseiffeli (Deflandre and Fert)

Tubodiscus verenae Thierstein

Rucinolithus wisei Thierstein

Biscutum sp.

Braarudosphaera sp.

Broinsonia sp.

Corollithion sp.

Cretarhabdus sp.

Eiffellithalid sp.

Micrantholithus sp.

Nannoconus sp. (small specimens)

Podorhabdus sp.

Vekshinella sp.

Watznaueria sp.

Zeugrhabdotus sp.

Zygodiscus sp.

calathina oblongata (Worsley), and Diadorhombus rectus Worsley to the last occurrence of Cruciellipsis cuvillieri (Manivit) and Bipodorhabdus colligatus (Black).

Stage: Lower Valanginian to upper Hauterivian.

Remarks: We could not divide the interval cored in Hole 416A into two zones. According to Thierstein (1971) the Cretarhabdus angustiforatus Zone is defined as the interval from the first occurrence of Cretarhabdus angustiforatus (Black) to the first occurrence of Calcicalathina oblongata (Worsley). At Hole 416A Calcicalathina oblongata (Worsley) is first present in Sample 416A-48-1, 86-87 cm, below the first occurrence of Cretarhabdus angustiforatus (Black) in Sample 416A$46, \mathrm{CC}$. It is not clear whether a hiatus exists between the Berriasian and Valanginian. If that were the case we would expect the first occurrence of Cretarhabdus angustiforatus (Black) and of Calcicalathina $o b$ longata (Worsley) to be in the same sample. Also, the presence of Cretarhabdus angustiforatus (Black) in the lower part of this interval is sporadic and specimens are relatively rare.

The top of this stratigraphic interval was designated as upper Hauterivian. Indeed, it is unlikely that the entire Hauterivian stage is represented. This conclusion is reached on the basis of the persistent occurrence of Bipodorhabdus colligatus (Black) and Cruciellipsis cuvillieri (Manvit) throughout the interval. Both species became extinct in the late Hauterivian (Thierstein, 1971,
1976). Although reworking by turbidity currents could have extended their occurrences upward beyond their actual range, we doubt that they would have occurred so persistently and in such a well-preserved state had they been redeposited. Moreover, species that would indicate deposition earlier than early Hauterivian are lacking. These include Lithraphidites bollii (Thierstein) and particularly Nannoconus bucheri Brönnimann. The highest occurrence of Rucinolithus wisei Thierstein which we found in Sample 31-5, 8-9 cm corresponds to a midValanginian datum level. However, this datum is no more reliable than other highest occurrences within this interval, and, inasmuch as the species was not found higher in the section, it may be simply that it was so rare among other indigenous and redeposited species that its presence escaped notice.

This stratigraphic interval was recognized only in the interval from Sample 416A-48-1, 86-86 cm through Sample 416A-7-1, $18 \mathrm{~cm}$.

\section{Micrantholithus obtusus Zone}

We did not recognize this zone in the samples studied.

\section{Chiastozygus litterarius Zone}

Author: Thierstein (1971), modified by Thierstein (1973).

Definition: Interval from the last occurrence of Nannoconus colomii (de Lapparent) and (or) the first occurrences of Chiastozygus litterarius (Gorka) and (or) Rucinolithus irregularis Thierstein to the first occurrence of Parhabdolithus angustus (Stradner) and (or) Lithastrinus floralis (Stradner).

Important common species: Chiastozygus litterarius (Gorka).

Stage: Lower Aptian.

Remarks: This zone was recognized only in Sample $416 \mathrm{~A}-6, \mathrm{CC}$. The sample contains a moderately wellpreserved and relatively diverse assemblage of coccoliths with Chiastozygus litterarius (Gorka) but without Nannoconus colomii (de Lapparent), Parhabdolithus angustus (Stradner) and Lithastrinus floralis (Stradner). The rest of Core 416A-6 lacks calcareous nannofossils. The lower and upper limits of the Chiastozygus litterarius Zone are difficult to recognize because the cores above Core 416A-7 were taken at widely spaced intervals. The poorly sampled section may also explain the absence of the Micrantholithus obtusus Zone and the Parhabdolithus angustus Zone.

\section{Parhabdolithus angustus Zone}

We did not recognize this zone in the samples studied.

\section{Predicosphaera cretacea Zone}

Author: Thierstein (1971), modified by Thierstein (1973).

Definition: Interval from the first occurrence of Predicosphaera cretacea (Arkhangelsky) to the first occurrence of Eiffellithus turriseiffeli (Deflandre and Fert).

Important common species: Prediscosphaera cretacea (Arkhangelsky), Corollithion achylosum (Stover), 


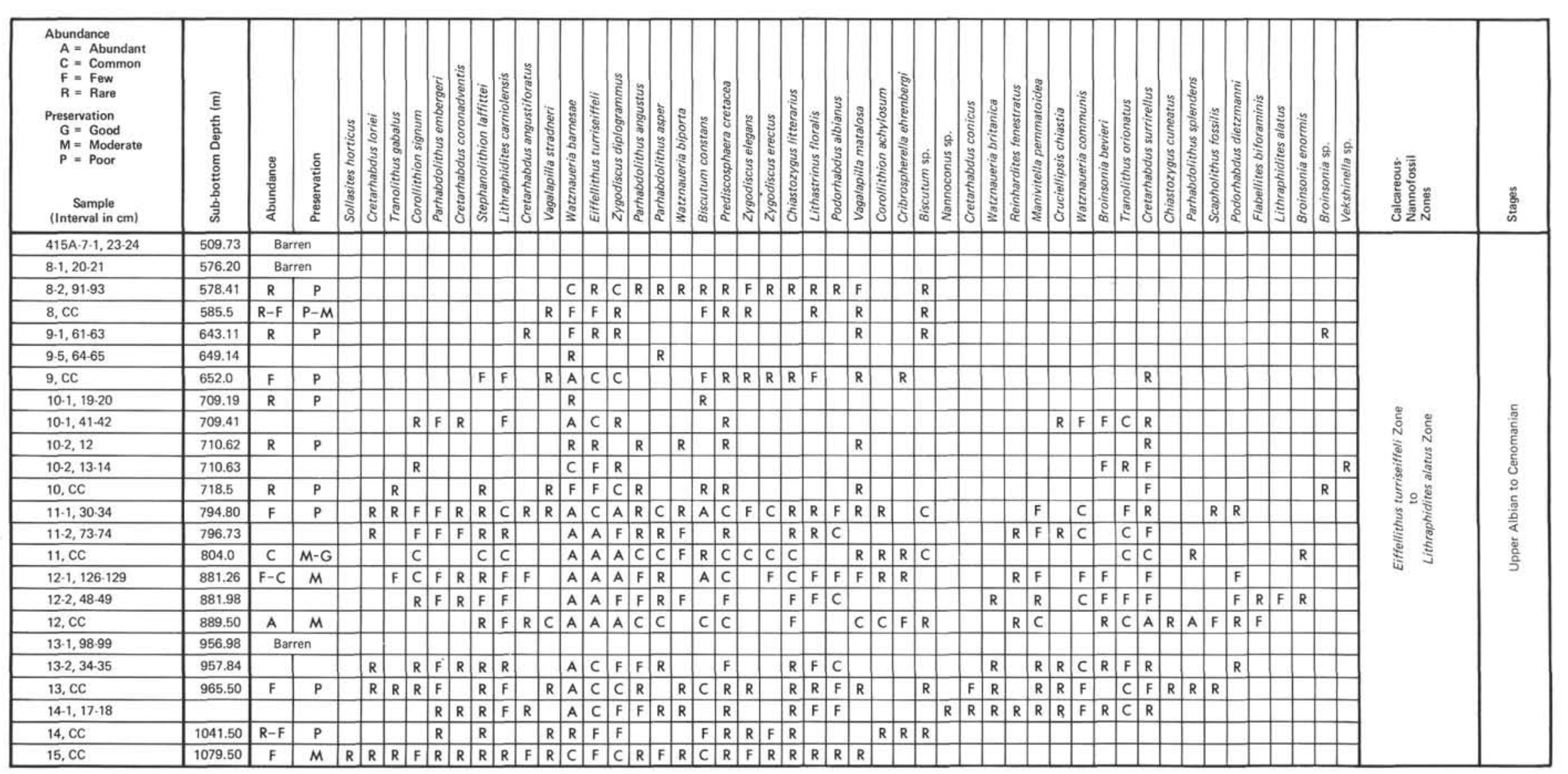

Figure 4. Distribution of Cretaceous nannofossils, Hole 415A. 
Parhabdolithus angustus (Stradner), Cretharhabdus coronadventis Reinhardt, and Mitosia infinitae Worsley.

Stage: Middle Albian.

Remarks: Sample 416A-5, CC was designated as middle Albian. The lower limit of this interval is defined by the presence of Prediscosphaera cretacea (Arkhangelsky), Cretharhabdus coronadventis Reinhardt, and Corollithion achylosum (Stover); the upper limit is defined by the first occurrence of Eiffelithus turriseiffeli (Deflandre). We cannot establish the thickness of this zone, because no cores were taken for 128 meters below Core $416 \mathrm{~A}-5$. The youngest Cretaceous sediments recovered at Hole $416 \mathrm{~A}$ are middle Albian. Sample 416A-5-1, 34-35 cm contains middle-Eocene calcareous nannofossils which demonstrate the presence of a hiatus from middle Albian to middle Eocene.

\section{Eiffellithus turriseiffeli Zone to Lithraphidites alatus Zone}

This stratigraphic zone is defined as the interval from the first occurrence of Eiffellithus turriseiffeli (Deflandre and Fert) to the first occurrence of Corollithion exiguum (Stradner).

Important common species: Eiffellithus turriseiffeli (Deflandre), Lithraphidites alatus (Thierstein), Cruciellipsis chiastia (Worsley), and Podorhabdus albianus Black.

\section{Stage: Upper Albian to Cenomanian.}

Remarks: We cannot assign a more precise age to this interval on the basis of calcareous nannofossils because we are dealing with a residual assemblage, one in which many forms, including key species, have been removed by dissolution. We base the age assignment for this interval largely on the co-occurrence of Eiffellithus turriseiffeli (Deflandre), Cruciellipsis chiastia (Worsley), Lithraphidites alatus Thierstein, and Podorhabdus albianus Black, and on the absence of Corollithion exiguum Stradner and Gartnerago obliquum (Stradner). (Stradner).

This stratigraphic interval was recognized only at Site 415 between Samples 415A-15, CC through 415A-7-1, 23-24 cm.

The following Cretaceous zones were not recognized at Sites 415 and 416: Corollithion exiguum Zone, Micula decussata-Tetralithus pyramidus Zone, Marthasterites furcatus Zone, Gartnerago obliquum Zone, Eiffellithus eximius Zone, Broinsonia parca Zone, Tetralithus trifidus Zone, and Lithraphidites quadratus Zone.

\section{Micula mura-Naphrolithus frequens Zone}

Authors: Čepek and Hay (1969).

Definition: Interval from the first occurrence of $\mathrm{Ne}$ phrolithus frequens (Gorka) and (or) Micula mura (Martini) to the level of extinction of most Upper Cretaceous species ("Cretaceous/Tertiary boundary").

Important common species: Micula mura (Martini) and Lithraphidites quadratus Bramlette and Martini.

Remarks: We recognized upper Maestrichtian sediments only in Samples 415A-6-2, 32-33 cm and 415A$6-2,27-23 \mathrm{~cm}$. The nannofossils in these samples are Late Cretaceous species with no admixture of Ceno- zoic species. The samples above and below these upperMaestrichtian samples yielded the following results.

\begin{tabular}{ll}
\hline Sample (Interval in cm) & \multicolumn{1}{c}{ Stratigraphic Interval } \\
\hline 415A-6-1, 74-75 & $\begin{array}{l}\text { Tertiary } \\
\text { Tertiary-not older than Cruciplacolithus } \\
\text { 415A-nuis Zone, NP 2 }\end{array}$ \\
415A-6-2, 27-28 & $\begin{array}{l}\text { Upper Maestrichtian } \\
\text { Upper Maestrichtian } \\
\text { 415A-6-2, 32-33 }\end{array}$ \\
415A-6-2, 94-95 & $\begin{array}{c}\text { Tertiary-not older than Cruciplacolithus } \\
\text { tenuis Zone, NP 2 }\end{array}$ \\
415A-6-2, 132-133 & Tertiary
\end{tabular}

These results may indicate that the upper-Maestrichtian sediments are allochthonous in the Tertiary section.

\section{Hiatuses}

We detected no hiatuses in the Lower and Middle Cretaceous sequences of Sites 415 and 416. But at Hole $416 \mathrm{~A}$, a long hiatus, representing some $70 \mathrm{~m} . \mathrm{y}$., is present between the upper Hauterivian and lower Eocene.

\section{DISTRIBUTION OF CALCAREOUS NANNOFOSSILS}

\section{Site 415 (latitude $31^{\circ} 01.72^{\circ} \mathrm{N}$; longitude $11^{\circ} 39.11^{\circ} \mathrm{W}$; water depth $2794 \mathrm{~m}$ )}

Site 415 is located in Agadir Canyon (Figure 1; Table 2) about 100 miles south from Sites 370 (Leg 41) and 416. The total depth drilled in Hole 415A was 1079.5 meters. The uppermost Cretaceous sediments containing a nannofossil assemblage of the Micula muraNephrolithus frequens Zone appear in Samples $415 \mathrm{~A}-6-2,27-28 \mathrm{~cm}$ and $415 \mathrm{~A}-6-2,32-33 \mathrm{~cm}$. They are not older than upper Maestrichtian, but inasmuch as lower-Paleocene sediments (Cruciplacolithus tenuis Zone; NN 2) occur above and below this level, the Maestrichtian assemblage may be allochthonous. The upper-Maestrichtian sediments are marlstone. The same type of sediment (partly mudstone), with layers of limestone, shale, fine sandstone, and calcarenite in Samples 415A-7-1, 23-24 cm through 415A-15, CC, composes the upper Albian to Cenomanian. The coccolith assemblages are generally poor with rare to few specimens. In the core-catcher samples from Cores $415 \mathrm{~A}-11$ and $415 \mathrm{~A}-12$, however, coccoliths are common to abundant and are moderately well-preserved. This stratigraphic level yielded assemblages of 43 species, including Eiffellithus turriseiffeli (Deflandre), Lithraphidites alatus (Thierstein), Cruciellipsis chiasta (Worsley), and Podorhabdus albianus (Black), but without Corollithion exiguum (Stradner) and Gartnerago obliquum (Stradner). This assemblage indicates that the samples fall in the Eiffellithus turriseiffeli Zone to Lithraphidites alatus Zone. Lithraphidites alatus (Thierstein) was recognized in only one sample (415A-12-2, $48-49 \mathrm{~cm})$, and we therefore cannot be certain that this one occurrence of only a few specimens can adequately define the Lithraphidites alatus Zone. 


\section{Site 416 (latitude $32^{\circ} 50.18$ ' $\mathrm{N}$; longitude $10^{\circ} 48.06$ ' $\mathrm{W}$; water depth $4191 \mathrm{~m}$ )}

Site 416 was drilled in a deep basin off Morocco (Figure 1) only $2 \mathrm{~km}$ from Site 370 (Leg 41). Hole 416A comprises a 1624-meter section. The Mesozoic sediments recovered from Hole 416A, from 762 to 1624 meters, are divided into three lithological units within which five stratigraphic horizons, extending from Tithonian to middle Albian, are recognized. The three youngest stratigraphic levels correlate very well with Site 370 of Leg 41 Čepek, 1978). The combination of results from both sites provides a good basis for a reconstruction of the Tithonian to Lower Cretaceous stratigraphy of the Moroccan Basin.

The sediments at the top of the Cretaceous are claystone, silty claystone with some siltstone, and fine sandstone. A poorly preserved but diverse assemblage of coccoliths occurs in the upper part of this unit. Sample 416A-5, CC contains Prediscosphaera cretacea (Arkhangelsky), Parhabdolithus asper (Stradner), Cretarhabdus coronadventis (Reinhardt), and Corollithion achylosum (Stover). The presence of Prediscosphaera cretacea (Arkhangelsky) indicates that the assemblage is not older than middle Albian. The absence of Eiffellithus turriseiffeli (Deflandre and Fert) indicates that the assemblage is not younger than middle Albian. But the absence of this key species could also result from poor preservation. These middle-Albian sediments correspond to the middle Albian of Core 370.25. The upper boundary of this stratigraphic interval is well defined because Sample 416A-5-1, 34-35 cm contains an assemblage of middle-Eocene nannofossils (Zones NP 13-NP 14), which shows that a hiatus exists from middle Albian to middle Eocene. We cannot designate the lower boundary of this interval because the 128-meter interval between Cores 416A-5 and 416A-6 was not cored.

The lower part of this sedimentological unit is lower Aptian. The lower-Aptian sediments were recovered only in the core-catcher sample of Core 416A-6, and they belong to the Chiastozygus litterarius Zone. The rest of this core lacks coccoliths. Nannofossils are sparse to common and are moderately well preserved. The assemblage includes Chiastozygus litterarius (Gorka) but lacks Parhabdolithus angustus (Stradner) and Lithastrinus floralis (Stradner). The sediments of Cores $370-32$ and $370-33$ of Site 370 (Leg 41) are the same age. About 95 meters were drilled without coring between Cores 416A-6 and 416A-7; thus, we cannot determine the thickness of the lower-Aptian sediments.

The upper-Hauterivian to lower-Valanginian sediments are represented within the unit of turbidites. For the most part this section consists of calcareous and quartzose fine sandstone, siltstone, and mudstone. Only at the base of this stratigraphic interval does the turbidite unit have siltstone and mudstone with hard micrite and calcarenite. Core 416A-7 was taken at a depth between 982 and 1093 meters, and consequently we cannot establish the exact depth of the 4.5-meter core. The age between this core down to Sample 416A-48-1, 86-87 cm is recognized by the presence of Cruciellipsis cuvillieri
(Manvit) (upper limit), Bipodorhabdus colligatus (Black) (upper and lower limit), Diadorhombus rectus (Worsley) (lower limit), and Calcicalathina oblongata (Worsley) (lower limit). This assemblage identifies the Lithraphidites bollii Zone to the Cretarhabdus angustif oratus Zone, but the zone species Lithraphidites bollii (Thierstein) was not observed in the samples. Coccolith assemblages are rare to sparse within this interval and are poorly to moderately well preserved. The upper part of this stratigraphic interval corresponds to the Lithraphidites bollii Zone to the Calcicalathina oblongata Zone at Site 370 of Leg 41.

The sediments of Samples 416A-48, CC through $416 \mathrm{~A}-53-2,26 \mathrm{~cm}$ are lithologically similar to those at the base of the upper Hauterivian to lower-Valanginian interval. The nannofossils, however, fall in the Berriasian Nannoconus colomii Zone. Coccoliths in this interval are sparse to common and are poorly to moderately well preserved. We recognized the base of the Nannoconus colomii Zone by the first occurrence of Parhabdolithus asper (Stradner) and the first occurrence of abundant Polycostella senaria (Thierstein). The top of this zone is marked by the first occurrence of Bipodorhabdus colligatus (Black), Calcicalathina oblongata (Worsley), Diadorhombus rectus (Worsley), and Tubodiscus verenae (Thierstein). The Berriasian was not reached at Site 370 (Leg 41).

The Jurassic sediments of the Tithonian Parhabdolithus embergeri Zone are lithologically similar to those of the Berriasian, and were recovered in Samples $416 \mathrm{~A}-53-2,45-46 \mathrm{~cm}$ to $416 \mathrm{~A}-57, \mathrm{CC}$ (base of hole). The assemblages include a few specimens of Parhabdolithus embergeri (Noel), Conusphaera mexicana (Trejo), and Polycostella beckmanii (Thierstein), but lack exclusively Cretaceous species. The specimens are poorly to moderately well preserved.

\section{ACKNOWLEDGMENTS}

Primary support for the study was provided in part by the Deutsche Forschungsgemeinschaft and by the Bundesanstalt für Geowissenschaften und Rohstoffe (Čepek).

\section{REFERENCES}

Arkhangelsky, A. D., 1912. Upper Cretaceous deposits of east European Russia, Mater. Geol. Russ., v. 25.

Barnard, T. and Hay, W. W., 1974. On Jurassic Coccoliths: A tentative zonation of the Jurassic of southern England and north France, Ecolog. Geol. Helv., v. 67, p. 563-585.

Black, M., 1964. Cretaceous and Tertiary coccoliths from Atlantic seamounts, Paleontology, v. 7, p. 306-316.

Bramlette, M. N. and Martini, E., 1964. The great change in. calcareous nannoplankton fossils between Maestrichtian and Danian, Micropaleontology, v. 10, p. 291-322.

Bukry, D., 1969. Upper Cretaceous coccoliths from Texas and Europe, Univ. Kansas Paleont. Contrib., Art. 51 (Protista 2), v. 2 .

1974. Coccolith stratigraphy, offshore Western Australia, Deep Sea Drilling Project, Leg 27. In Veevers, J.J., Heirtzler, J.R., et al., Initial Reports of the Deep Sea Drilling Project, v. 27: Washington (U.S. Government Printing Office), p. 623-630.

Bukry, D. and Bramlette, M. N., 1970. Coccolith age determination Leg 3, Deep Sea Drilling Project. In Maxwell, 
A.E., et al., Initial Reports of the Deep Sea Drilling Project, v. 3: Washington (U.S. Government Printing Office), p. 589-611.

Čepek, P., 1970. Zur Vertikalverbreitung von Coccolithen Arten in Oberkreide NW-Deutschland, Geol. Jb., v. 88, p. 235-264.

1978. Mesozoic calcareous nannoplankton of the eastern north Atlantic, Leg 41. In Seibold, E., Lancelot, Y., et al., Initial Reports of the Deep Sea Drilling Project, v. 41: Washington (U.S. Government Printing Office), p. 667-687.

Čepek, P. and Hay, W. W., 1969. Calcareous nannoplankton and biostratigraphic subdivision of the Upper Cretaceous, Gulf Coast Assoc. Geol. Soc. Trans., v. 19, p. 323-336.

Deflandre, G. and Fert, C., 1954. Observations sur les Coccolithophorides actuels et fossiles en microscopie ordinaire et electronique, Ann. Paleontol., v. 40, p. 115-176.

Gartner, S., 1968. Coccoliths and related calcareous nannofossils from Upper Cretaceous deposits of Texas and Arkansas, Univ. Kansas Paleontol. Contrib., v. 48, p. 1-56.

Lancelot, Y., Winterer, E. L., et al., 1977. Documenting early rifting, Geotimes, v. 22 , no. 4, p. 24-27.

Loeblich, A. R., Jr. and Tappan, H., 1966. Annotated index and bibliography of the calcareous nannoplankton, Phycologia, v. 5, p. 81 .

1968. Annotated index and bibliography of the calcareous nannoplankton II, J. Paleontol., v. 42, p. 584-598.

1969. Annotated index and bibliography of the calcareous nannoplankton, III, J. Paleontol., v. 43, p. 568-588.

1970a. Annotated index and bibliography of the calcareous nannoplankton IV, J. Paleontol., v. 44, p. 558-574.

1970b. Annotated index and bibliography of the calcareous nannoplankton V, Phycologia, v. 9, p. 157.

Manivit, H., 1965. Nannofossils calcaires de l'Albo-Aptien, Rev. Micropal., v. 8, p. 189-201.

1971. Les nannofossiles du Cretace français de l'Aptien au Danien: Essai de biozonation appuyee sur les stratotypes, These Fac. Science d'Orsay.

Moshkovitz, S., 1972. Biostratigraphy of the genus Nannoconus in the Lower Cretaceous sediments of the subsurface: Ashgelon-Helez area, Central Israel, Israel J. Earth Sci., v. 21 , p. $1-28$.

Noel, D., 1965. Sur les Coccolithes du Jurassique Europeen et d' Afrique du Nord: Essai de Classification Fossiles, Ed. Centre Nat. Rech. Sci.

Prins, B., 1969. Evolution and stratigraphy of Coccolithinids from the Lower and Middle Lias, First Int. Conf. Plankt.
Microfoss. Proc. Geneva: Leiden (E.J. Brill), v. 2, p. $547-$ 558.

Rood, A. P., Hay, W. W., and Barnard, T., 1971. Electron microscope studies of Oxford clay coccoliths, Eclog. Geol. Helv., v. 64, p. 245-272.

Roth, P. H., 1973. Calcareous nannofossils Leg 17 Deep Sea Drilling Project. In Winterer, E.L., Ewing, J.I., et al., Initial Reports of the Deep Sea Drilling Project, v. 17: Washington (U.S. Government Printing Office), p. 695-796.

Roth, P. H. and Thierstein, H. R., 1972. Calcareous nannoplankton: Leg 14 of the Deep Sea Drilling Project. In Hayes, D.E., Pimm, A.C., et al., Initial Reports of the Deep Sea Drilling Project, v. 14: Washington (U.S. Government Printing Office), p. 421-485.

Sissingh, W., 1977. Biostratigraphy of Cretaceous calcareous nannoplankton, Geol. Mijnbouw, v. 56, p. 37-65.

Stover, L. E., 1966. Cretaceous coccoliths and associated nannofossils from France and the Netherlands, Micropaleontology, v. 12 , p. 133-167.

Stradner, H., 1963. New contributions to Mesozoic stratigraphy by means of nannofossils, Sixth World Petrol. Congr. Proc. (Frankfurt. am M.) Sect. 1, paper 4.

Stradner, M., Adamiker, D., and Maresch, O., 1968. Electron microscope studies on Albian calcareous nannoplankton from the Delft 2 and Leidschendam 1 deep wells, Holland, Verh. K. Ned. Akad. Wetsch, Afd. Natuurk, Eerste Reeks, v. 24 , p. 1-107.

Thierstein, H. R., 1971. Tentative Lower Cretaceous calcareous nannoplankton zonation, Eclog. Geol. Helv., v. 64, p. $459-488$. 1973. Lower Cretaceous calcareous nannoplankton biostratigraphy, Abl. Geol. Bundesanst. Wien, v. 29. 1974. Calcareous nannoplankton-Leg 26, Deep Sea Drilling Project. In Davies, T.A., Luyendyk, B.P., et al., Initial Reports of the Deep Sea Drilling Project, v. 26: Washington (U.S. Government Printing Office), p. 619-668.

1975. Calcareous nannoplankton biostratigraphy at the Jurassic-Cretaceous boundary, Mem. Bur. Rech. Geol. Min., v. 86, p. 84-94.

1976. Mesozoic calcareous nannoplankton biostratigraphy of marine sediments, Marine Micropaleontol., v. 1, p. 325-362.

van Hinte, J. E., 1976. A Cretaceous time scale, Am. Assoc. Petrol. Geol. Bull., v. 60, p. 498-516.

Worsley, T., 1971. Calcareous nannofossil zonation of Upper Jurassic and Lower Cretaceous sediments from the western Atlantic. In Farinacci, A. (Ed.), Second Plankt. Conf. Proc. Roma 1970: Rome (Tecnoscienza), v. 2, p. 1301-1322. 